\title{
Perilaku Membuang Sampah Makanan dan Pengelolaan Sampah Makanan di Berbagai Negara: Review
}

\author{
Mochammad Chaerul dan Sharfina Ulfa Zatadini
}

Program Studi Magister Teknik Lingkungan, Fakultas Teknik Sipil dan Lingkungan, Institut Teknologi Bandung; e-mail: m.chaerul@ftsl.itb.ac.id

\begin{abstract}
ABSTRAK
Dalam beberapa tahun terakhir, sampah makanan mejadi salah satu isu global. Peningkatan timbulan sampah makanan dapat menimbulkan masalah bagi rantai penyediaan makanan dan pelestarian lingkungan secara global di masa mendatang. Sampah makanan dapat dihasilkan pada semua tahap rantai pasokan makanan. Salahsatu kontributor utama dalam peningkatan timbulan sampah makanan di suatu wilayah adalah sektor rumahtangga. Tujuan studi ini untuk memberikan suatu tinjauan terhadap berbagai studi tentang food waste behavior, yaitu perilaku seseorang terkait sampah makanan dan konsep pengelolaan sampah makanan pada sektor rumah tangga yang dapat diterapkan di Indonesia berdasarkan implementasi pengelolaan sampah makanan di beberapa Negara. Selain dari berbagai macam laporan terkait pengelolaan sampah makanan di berbagai Negara, studi ini juga mereview paper ilmiah yang telah dipublikasikan di berbagai jurnal internasional. Pendekatan psikologi termasuk perilaku, keadaan sosio-demografi, dan rutinitas dan praktik terkait perencanaan makanan diidentifikasi ke dalam faktor yang mempengaruhi peningkatan timbulan sampah makanan. Selanjutnya, dapat ditentukan strategi pencegahan dan pengurangan sampah makanan dari faktor yang telah teridentifikasi diatas. Beberapa Negara telah mencoba melakukan pengelolaan sampah makanan secara terpadu dalam suatu sistem pengelolaan sampah skala Kota dimana kunci keberhasilannya adalah dilakukannya pemilahan sampah makanan yang lebih baik mulai di sumber untuk lebih memaksimalkan potensi pemanfaatannya di tahapan penanganan selanjutnya. Konsep yang serupa dapat pula diaplikasikan untuk kondisi Indonesia, terlebih dengan mempertimbangkan proporsi sampah makanan yang cukup signifikan ditemui dalam aliran sampah di area perkotaan.
\end{abstract}

Kata kunci: Sampah makanan, Perilaku, Jurnal internasional, Laporan, Review, Pemilahan, Pemanfaatan, Sampah perkotaan, Area perkotaan

\begin{abstract}
In last few years, food waste becomes a global issue. Increasing of food waste generation leads to various problems for food supply chain and for environmental preservation globally in the future. Food waste could be generated from all stages of food supply chain. A main contributor for increasing food waste generation in a region is household sector. The study aims to provide a review of various previous studies related to food waste behavior and concept of food waste management from household that may be adopted for Indonesia based on best practices of those in several countries. In addition of those countries'report, the study reviews scientific papers that have been already published in several international journals. Psychological approach such as behavior, socio-demogrphic situation, and habit and practices related to a food preparation was identified to be an influencing factor for increasing food waste. Subsequently, measures for prevention and reduction of food waste from the factor indentified above. Several countries attempt to conduct the integrated food waste management within municipal solid waste management in a city in which the key to its success is a better food waste segregation starting at source to maximize the recovery in the next stage of handling system. In fact, similar concept could be adopted for Indonesian situation, especially by considering the siginficant proportion of food waste found in the stream of municipal solid waste from urban area.
\end{abstract}

Keywords: Food waste, Behavior, International journals, Reports, Review, Segregation, Recovery, Municipal solid waste, Urban area.

Citation: Chaerul, M. dan Zatadini, S.U. (2020). Perilaku Mebuang Sampah Makanan dan Pengelolaan Sampah Makanan di Berbagai Negara: Review. Jurnal Ilmu Lingkungan, 18(3), 455-466, doi:10.14710/jil.18.3.455-466

\section{Pendahuluan}

Manusia membutuhkan makan untuk bertahan hidup, sampah makanan akan terus dihasilkan setiap harinya. Isu kehilangan makanan (food loss) dan sampah makanan semakin mendapatkan perhatian di seluruh dunia (Nikolaus et al., 2018). Tantangan global yang akan dihadapi masyarakat seluruh dunia adalah penyediaan makanan bagi 9,1 miliar orang pada tahun 2050 (Abdelradi, 2018). Hal ini 455 menunjukkan bahwa timbulan sampah makanan yang dihasilkan cukup besar. Badan Perserikatan BangsaBangsa (PBB) yang menurusi pangan (Food and Agriculture Organization/FAO) memperkirakan sekitar 32\% dari makanan yang diproduksi terbuang begitu saja pada tahun 2009 (Parfitt et al., 2010). Nilai ini diperhitungkan dari massa kehilangan makanan dan sampah makanan serta tidak termasuk energi yang hilang. Diperlukan solusi yang memiliki dampak 
Chaerul, M. dan Zatadini, S.U. 2020. Perilaku Mebuang Sampah Makanan dan Pengelolaan Sampah Makanan di Berbagai Negara: Review. Jurnal Ilmu Lingkungan, 18(3), 455-466, doi:10.14710/jil.18.3.455-466

jangka panjang untuk menyelesaikan masalah tersebut.

Kehilangan sampah makanan terjadi pada hulu rantai pasokan makanan dan tidak termasuk retailer, layanan jasa makanan, dan konsumen (FAO, 2011). Menurut FAO (2011) dan Food Use for Social Innovation by Optimising waste prevention Strategies / FUSIONS (2014), sampah makanan adalah sampah yang terbuang pada tahap konsumsi di akhir rantai pasokan makanan. Perbedaannya adalah FUSIONS (2014) memasukkan komponen makanan yang tidak bisa dimakan ke dalam kategori sampah makanan.

Sektor rumah tangga menjadi salah satu sektor yang menyumbang sampah makanan dalam jumlah yang cukup besar. Terdapat berbagai faktor yang mempengaruhi timbulan sampah makanan. Salah satunya adalah perilaku seseorang terhadap sampah makanan atau biasa disebut dengan food waste behavior yang diinvestigasi dari perspektif perilaku konsumen. Faktor lain dapat mempengaruhi food waste behavior dengan secara tidak langsung mempengaruhi perilaku konsumen (Hebrok \& Boks, 2017, Ilyuk, 2018). Faktor tersebut meliputi aspek material dalam suatu keluarga termasuk kondisi hidup dan akses geografis terhadap transportasi dan toko yang mempengaruhi rutinitas harian food waste behavior dalam rumah tangga. Pengetahuan, kemampuan, dan perilaku yang buruk terkait perencanaan makanan dapat meningkatkan timbulan sampah makanan (Van der Werf et al., 2019).

Banyak negara yang mulai melakukan pengembangan dan perbaikan terhadap strategi pengelolaan sampah khususnya untuk sampah makanan. Kecenderungan untuk menghasilkan sampah makanan lebih besar pada negara maju dibandingkan dengan negara berkembang (Abdelradi,
2018). Pengelolaan sampah makanan yang diterapkan dengan baik diharapkan dapat mengurangi timbulan sampah makanan.

Di Indonesia, sampah makanan belum mendapatkan perhatian secara khusus padahal potensi yang dimiliki sangat besar bila dilakukan pengelolaan yang lebih baik. Oleh karena itu, dirasakan perlu untuk melakukan review dari berbagai macam penelitian terkait perilaku seseorang terhadap sampah makanan (food waste behavior) dan pengalaman pengelolaan sampah makanan yang dilakukan oleh berbagai Negara sebagai pengalaman untuk diapolikasikan di Indonesia. Review dilakukan terhadap paper-paper ilmiah yang telah dipublikasikan di berbagai jurnal, terutama yang di jurnal internasional, dan laporan-laporan terkait pengelolaan sampah makanan di berbagai Negara. Paper ini juga bertujuan menjadi salah satu acuan dalam pengembangan pengelolaan sampah makanan yang dapat dikembangkan untuk kondisi perkotaan di Indonesia.

\section{Metodologi}

Dalam studi ini, diulas mengenai perilaku masyarakat rumah tangga terkait dengan sampah makanan dan strategi pengelolaan sampah makanan di berbagai negara. Ulasan tersebut diperoleh dari tinjauan literatur melalui jurnal internasional dan laporan tahunan lainnya. Basis data ScienceDirect paling banyak digunakan sebagai dasar pencarian literatur jurnal internasional. Sementara itu, laporan diperoleh dari laporan tahunan yang dibuat oleh asosiasi internasional seperti UNDP dan World Association Biogas maupun laporan resmi dari suatu negara. Tabel 1 dan Tabel 2 memberikan data jurnal dan laporan yang digunakan dalam studi.

Tabel 1. Jurnal tentang Food Waste Behavior dan Pengelolaan Sampah Makanan yang Diidentifikasi

\begin{tabular}{|c|c|c|c|}
\hline Sumber & $\begin{array}{c}\text { Lingkup Analisis } \\
\text { Geografis }\end{array}$ & Metodologi & Fokus Analisis \\
\hline Nikolaus et al., 2018 & Amerika Serikat & Analisis Inductive thematic & Perceptions, beliefs and behaviors \\
\hline Lee et al., 2011 & Korea & $\begin{array}{l}\text { Kuesioner dengan multiple } \\
\text { regression model }\end{array}$ & $\begin{array}{l}\text { Food waste behavior dan pengelolaan } \\
\text { sampah makanan }\end{array}$ \\
\hline Ng et al., 2017 & Singapura & Material Flow Analysis & Pengelolaan sampah makanan \\
\hline Lim et al., 2016 & Malaysia & Literatur & Pengelolaan sampah makanan \\
\hline Abdelradi, 2018 & Kairo & $\begin{array}{l}\text { Kuesioner dengan Structural } \\
\text { Equation Model (SEM) }\end{array}$ & Food waste behavior \\
\hline Russel et al., 2017 & United Kingdom & $\begin{array}{l}\text { Kuesioner } 4 \text { fase dengan } \\
\text { Structural Equation Model (SEM) }\end{array}$ & $\begin{array}{l}\text { Food waste behavior berdasarkan } \\
\text { theory of planned behavior }\end{array}$ \\
\hline Mattar et al., 2018 & Lebanon & $\begin{array}{l}\text { Interview, kuesioner, dan self- } \\
\text { reported questionnaire dengan } \\
\text { regresi logistik }\end{array}$ & Food waste behavior \\
\hline Schanes et al., 2018 & Global & Analisis data kualitatif & $\begin{array}{l}\text { Tinjauan kritis praktik timbulan } \\
\text { sampah makanan di rumah tangga dan } \\
\text { implikasi kebijakan }\end{array}$ \\
\hline Grasso et al., 2019 & Denmark dan Spanyol & $\begin{array}{l}\text { Kuesioner dan self-reported } \\
\text { questionnaire dengan } \\
\text { Equation Model (SEM) }\end{array}$ & $\begin{array}{l}\text { Food waste behavior berdasarkan } \\
\text { kondisi sosio-demografi }\end{array}$ \\
\hline Amirudin \& Gim, 2019 & Klang Valley, Malaysia & $\begin{array}{l}\text { Kuesioner dan self-reported } \\
\text { questionnaire dengan Partial Least } \\
\text { Squares Structural Equation } \\
\text { Modelling (PLS-SEM) }\end{array}$ & Aksesibilitas Makanan FWB \\
\hline Van der Werf et al., 2019 & Ontario, London & $\begin{array}{l}\text { Kuesioner dan self-report dengan } \\
\text { path analysis }\end{array}$ & $\begin{array}{l}\text { Food waste behavior berdasarkan } \\
\text { theory of planned behavior }\end{array}$ \\
\hline
\end{tabular}


Tabel 2. Laporan tentang Pengelolaan Sampah Makanan yang Diidentifikasi

\begin{tabular}{ll}
\hline \multicolumn{1}{c}{ Sumber } & \multicolumn{1}{c}{ Lingkup Analisis Geografis } \\
\hline Jain et al., 2018 & Global \\
Yoo, 2019 & Seoul, Korea Selatan \\
NEA, 2020 & Singapura \\
\hline
\end{tabular}

Lingkup studi tidak terbatas pada suatu negara melainkan penerapan pengelolaan sampah makanan dari berbagai negara. Keterbatasan dari studi ini adalah identifikasi dilakukan secara kualitatif dan tidak memperhatikan faktor mana yang paling mempengaruhi adanya timbulan sampah makanan tetapi studi untuk mengetahui faktorfaktor apa saja yang dapat menimbulkan sampah makanan dan pengelolaan sampah makanan yang diterapkan di berbagai negara. Fokus studi terbatas pada timbulan sampah makanan pada sektor rumah tangga.

\section{Pembahasan}

\subsection{Metode dan Aspek dalam Studi Food Waste Behavior}

Berdasarkan review yang telah dilakukan, faktor-faktor yang diidentifikasi memiliki pengaruh terhadap food waste behavior atau perilaku seseorang dalam menghasilkan sampah makanan dianalisis melalui survei dengan metode yang paling banyak dilakukan adalah kuesioner dan metode lain yang dilakukan adalah interview. Terdapat dua jenis kuesioner, yaitu kuesioner umum dan self-report questionnaire. Kuesioner umum adalah kuesioner yang berisikan pertanyaan yang langsung dapat dijawab oleh responden dan dikembalikan pada peneliti. Berbeda dengan self-report questionnaire, responden harus melaporkan jawaban yang dipertanyakan dalam kuesioner sesuai dengan waktu yang telah ditentukan. Self-report questionnaire digunakan untuk mengetahui jenis dan jumlah sampah makanan yang dihasilkan pada rentang waktu tertentu. Umumnya, rentang waktu yang digunakan adalah 7 hari. Sementara itu, analisis yang umum digunakan adalah Structural Equation Model (SEM).

Hasil review menunjukan terdapat berbagai macam aspek yang dianalisis dan mempengaruhi food waste behavior, antara lain: sikap, norma, rutinitas perencanaan makanan, dan sosio-demografi. Penjelasan dari berbagai macam aspek tersebut diuraikan dalam bagian berikut.

\subsubsection{Sikap}

Sikap merupakan pola pikir yang dapat mendorong seseorang untuk melakukan perilaku tertentu (Russel et al., 2017). Dalam kasus membuang-buang makanan, hal ini menggambarkan apakah seseorang berpikir bahwa isu sampah makanan adalah isu yang penting dan perlu dilakukan usaha pengurangan sampah makanan (Van der Werf et al., 2019).
Seseorang yang mempertimbangkan membuang sampah makanan sebagai perilaku yang tidak baik dapat disebut sebagai orang yang peduli terhadap makanan yang dibuang. Perasaan merasa bersalah menjadi salah satu dorongan untuk mengurangi sampah makanan (Mattar et al., 2018). Banyak studi di Negara sedang berkembang yang menunjukkan bahwa pertimbangan terhadap keuangan merupakan salah satu motivasi seseorang untuk mereduksi sampah makanan (Graham-Rowe et al., 2014; Neff et al., 2015; Abdelradi, 2018; Amirudin \& Gim, 2019).

Pertimbangan dan perhatian terhadap adanya dampak lingkungan karena sampah makanan kurang menjadi perhatian konsumen sesuai dengan studi yang dilakukan Van der Werf et al. (2019). Amirudin \& Gim (2019) juga menyebutkan bahwa orang yang memiliki nilai-nilai lingkungan tidak serta-merta mau melakukan usaha pengurangan sampah makanan. Sementara itu, di Korea dan Negara maju lainnya, kepedulian terhadap lingkungan akan mengurangi timbulan sampah makanan. Akan tetapi, peningkatan kepedulian terhadap lingkungan didorong oleh adanya sistem biaya pengelolaan sampah makanan (Lee \& Paik, 2011).

\subsubsection{Norma dan Perceived Behavior Control}

Norma subjektif adalah perilaku yang dilakukan oleh seseorang akibat adanya tekanan sosial (Van der Werf et al., 2019). Norma subjektif tidak mempengaruhi perilaku seseorang dalam menghasilkan timbulan sampah makanan sesuai dengan studi yang dilakukan oleh Russel et al. (2017) dan Van der Werf et al. (2019). Perilaku dapat dipengaruhi oleh norma personal yang dapat didorong dari berbagai hal seperti nilai moral, perasaan bersalah, atau kepedulian terhadap lingkungan (Van der Werf et al., 2019). Menurut Visschers et al. (2016), norma personal merupakan prediktor yang signifikan terhadap timbulan sampah makanan yang dihasilkan.

Sementara itu, Perceived Behavior Control (PBC) adalah ukuran seseorang dalam meyakini bahwa dirinya memiliki kemampuan, sarana, dan peluang untuk melakukan perilaku tertentu (Russel et al., 2017). Lee \& Paik (2011) menyebutkan salah satu pengaruh perilaku mengelola sampah makanan dipengaruhi oleh adanya sikap mengelola makanan. PBC dianggap sebagai salah satu faktor yang mempengaruhi seseorang dalam menghasilkan timbulan sampah makanan. Hal ini dibuktikan oleh studi yang dilakukan oleh Russel et al. (2017) dan Van der Werf et al. (2019).

\subsubsection{Rutinitas Perencanaan Makanan}

Rutinitas dalam merencanakan makanan dianggap penting dan krusial dalam mempengaruhi timbulan sampah makanan yang dihasilkan (Schanes et al., 2018). Akan tetapi, rumah tangga dianggap terlalu meremehkan adanya timbulan sampah 
makanan (Mattar et al., 2018). Berikut ini adalah rutinitas perencanaan makanan dalam rumah tangga: a. Persiapan

Persiapan merupakan tahap awal dalam mencegah timbulan sampah makanan. Terdapat berbagai strategi yang dapat dilakukan dalam persiapan, seperti menulis daftar belanja, menyusun rencana makan, dan memeriksa inventori sebelum berbelanja (Schanes et al., 2018). Penggunaan daftar belanja ditemukan dapat mengurangi jumlah sampah makanan yang dibuang per kapita sekitar 20\% (Schanes et al., 2018). Sementara itu, memeriksa inventori sebelum berbelanja dapat mengurangi potensi pembelian yang tidak penting sehingga tidak menambah jumlah inventori yang sama. Rutinitas persiapan yang baik dilaporkan dapat mengurangi belanja yang tidak direncanakan (Schanes et al., 2018).

\section{b. Belanja}

Kegiatan belanja merupakan hal yang penting dalam perencanaan makanan. Belanja yang berlebih dapat berkontribusi pada timbulan sampah makanan yang berlebih. Hal ini dapat disebabkan oleh perbedaan selera antar anggota keluarga, penimbunan makanan agar dapat menghemat waktu, dan pembelian kemasan makanan yang besar karena harganya yang lebih murah (Schanes et al., 2018). Aspek biaya yang perlu dikeluarkan untuk membeli makanan merupakan suatu hal yang menjadi pertimbangan dalam belanja (Amirudin \& Gim, 2019). Semakin tidak penting baya bagi konsumen, maka semakin banyak jumlah makanan yang dibuang. Di samping itu, frekuensi kegiatan belanja juga dinilai dapat mempengaruhi peningkatan timbulan sampah makanan (Schanes et al., 2018). Akan tetapi, akses menuju tempat belanja menjadi suatu hal yang dapat berpengaruh terhadap frekuensi berbelanja (Amirudin \& Gim, 2019).

\section{c. Penyimpanan}

Setiap jenis makanan memiliki perlakuan yang berbeda-beda dalam penyimpanan. Selain itu, penyusunan makanan yang baik dapat mempermudah menjangkau makanan yang diinginkan sehingga tidak ada makanan yang tersembunyi dan lupa untuk digunakan. Mayoritas konsumen gagal dalam menerapkan strategi penyimpanan untuk meningkatkan masa pemakaian makanan (Schanes et al., 2018).

\section{d. Memasak}

Memasak dalam jumlah yang banyak dapat memicu timbulan sampah makanan yang berlebihan. Kemampuan memasak yang baik dapat membantu dalam mengurangi jumlah makanan yang terbuang. Hal ini dikarenakan dapat meningkatkan estimasi porsi yang sesuai dengan yang dibutuhkan (Schanes et al., 2018) serta mengurangi potensi membuangbuang makanan yang tidak penting.

\section{e. Praktik Cara Makan}

Hanya ada sedikit studi yang meneliti peran praktik makan dalam timbulan sampah makanan (Schanes et al., 2018). Umumnya, tahap makan dihubungkan dengan kondisi sosio-demografi suatu keluarga sehingga tidak dijelaskan pola makan tertentu yang dapat mendorong peningkatan timbulan sampah makanan.

\section{f. Penanganan Makanan Tersisa dan Pembuangan}

Sisa makanan dimaksudkan sebagai makanan yang tersisa dari suatu penyajian makanan karena penyediaan yang berlebih. Tidak semua orang mau memakan kembali sisa makanan karena pertimbangan ketahanan sisa makanan yang mengacu pada keamanan makanan jika tetap dikonsumsi. Di samping itu, menggunakan sisa makanan sebagai bahan untuk membuat menu makanan baru dianggap lebih sulit dan membutuhkan lebih banyak waktu (Schanes et al., 2018). Hal ini mengantarkan pada sisa makanan berakhir di pembuangan padahal sisa makanannya yang digunakan kembali dapat mengurangi potensi peningkatan timbulan sampah makanan di rumah tangga.

Sebenarnya, sampah makanan memiliki potensi dan dapat ditangani dengan cara mendaur ulangnya. Abdelradi (2018) melakukan studi di Kairo dan hasilnya adalah responden mendukung kegiatan daur ulang sampah yang dapat mengurangi timbulan sampah makanan. Berbeda dengan Amirudin \& Gim (2019) yang menyebutkan bahwa kegiatan daur ulang dan tindakan preventif tidak memiliki hubungan dengan nilai-nilai lingkungan yang dimiliki. Dengan kata lain, nilai lingkungan yang dimiliki tidak berdampak pada perilaku ramah lingkungan. Hal ini menunjukkan bahwa kegiatan daur ulang sampah dan tindakan preventif tidak serta merta dapat mengurangi timbulan sampah makanan.

\subsubsection{Sosio-Demografi}

Kondisi sosio-demografi di setiap negara bahkan daerah berbeda-beda. Terdapat pertentangan apakah sosio-demografi dapat mempengaruhi perilaku individu dalam menghasilkan sampah makanan. Pengaruh perilaku seseorang terhadap timbulan sampah makanan dapat berbeda-beda meski dengan kondisi sosio-demografi yang sama.

Grasso et al. (2019) melakukan penelitian di Denmark dan Spanyol. Hasilnya adalah usia dan status pekerjaan memiliki hubungan yang negatif dengan timbulan sampah makanan yang dihasilkan. Seseorang dengan usia yang lebih tua (di atas 65 tahun) memiliki kecenderungan untuk melakukan usaha pengurangan sampah makanan. Di samping itu, seseorang yang tidak memiliki pekerjaan cenderung menghasilkan sampah makanan dalam jumlah yang lebih sedikit dibandingkan dengan seseorang yang bekerja. Terdapat pengaruh sosio-demografi yang lain untuk Denmark, yaitu jenis kelamin dan jumlah anggota keluarga. Laki-laki dinilai menghasilkan lebih 
banyak sampah makanan dibandingkan perempuan. Hal ini seperti dengan studi yang ditemukan di Uni Eropa dan United States (Grasso et al., 2019), tapi berbeda dengan studi yang diteliti oleh Koivopuro et al. (2012) yang menyebutkan bahwa laki-laki menghasilkan sampah makanan yang lebih sedikit dibandingkan perempuan.

Jumlah anggota keluarga yang banyak akan menghasilkan timbulan sampah yang lebih banyak dibandingkan dengan anggota keluarga yang sedikit. Prediktor jumlah anggota keluarga juga dilaporkan mempengaruhi timbulan sampah makanan oleh studi yang dilakukan oleh Mattar et al. (2018) di Lebanon. Selain itu, prediktor pekerjaan, edukasi, dan pendapatan dinilai dapat mempengaruhi timbulan sampah makanan (Mattar et al., 2018).

\subsection{Strategi Pengelolaan Sampah Makanan}

Dalam rangka pelaksanaan usaha pengurangan sampah makanan, maka diperlukan strategi yang tepat dalam pengelolaan sampah makanan. Target pengurangan sampah rumah tangga dan sampah sejenis rumah tangga pada tahun 2025 adalah 30\% berdasarkan Peraturan Presiden Republik Indonesia Nomor 97 Tahun 2017. Sampah organik menjadi komposisi sampah yang dominan pada sebagian besar sampah kota di Indonesia (Damanhuri \& Padmi, 2010).

Tabel 3. Pencegahan Timbulan Sampah Makanan dari Aspek Persepsi terhadap Sampah Makanan

\begin{tabular}{|c|c|c|}
\hline & Tindakan untuk Mengurangi dan Mencegah Timbulan Sampah Makanan \\
\hline \multirow{4}{*}{$\begin{array}{l}\text { Alasan Menimbulkan Sampah Makanan } \\
\text { Kurangnya kesadaharan terhadap jumlah } \\
\text { sampah makanan yang dibuang }\end{array}$} & 1. & Retribusi yang sesuai dengan jumlah sampah makanan dibuang (K). \\
\hline & 2. & Pemberlakuan denda $(\mathrm{K})$. \\
\hline & 3. & $\begin{array}{l}\text { Kampanye dan sosialisasi terkait usaha pengurangan sampah yang dapat dilakukan } \\
(\mathrm{K}) \text {. }\end{array}$ \\
\hline & 4. & Meningkatkan ketersediaan data timbulan sampah makanan (P\&P). \\
\hline \multirow[t]{2}{*}{ Ketidakpedulian terhadap sampah makanan } & 1. & $\begin{array}{l}\text { Pemberian informasi terkait timbulan sampah makanan dapat menjadi masalah } \\
\text { lingkungan, ekonomi, dan sosial }(\mathrm{K}) \text {. }\end{array}$ \\
\hline & 2. & Regulasi terkait pengelolaan sampah makanan (K). \\
\hline $\begin{array}{l}\text { Ketidakpahaman dampak lingkung-an yang } \\
\text { ditimbulkan }\end{array}$ & 1. & $\begin{array}{l}\text { Pemberian informasi terkait contoh nyata dari pengaruh timbulan sampah makanan } \\
\text { terhadap lingkungan (P\&P). }\end{array}$ \\
\hline $\begin{array}{l}\text { Tidak percaya bahwa dirinya mampu } \\
\text { mengurangi timbulan sampah makanan }\end{array}$ & 1. & $\begin{array}{l}\text { Program edukasi dan kampanye terkait dengan kemudahan dalam mengelola } \\
\text { sampah makanan }(\mathrm{K}) \text {. }\end{array}$ \\
\hline
\end{tabular}
sampah makanan $(\mathrm{K})$.

Keterangan: B: Bisnis, K: Kebijakan, P\&P: Penelitian \& Pengembangan, RT:Rumah Tangga

Tabel 4. Pencegahan Timbulan Sampah Makanan dari Aspek Rutinitas Perencanaan Makanan

\begin{tabular}{|c|c|}
\hline Alasan Menimbulkan Sampah Makanan & Tindakan untuk Mengurangi dan Mencegah Timbulan Sampah Makanan \\
\hline \multicolumn{2}{|l|}{ Persiapaan } \\
\hline Kurangnya persiapan belanja & $\begin{array}{l}\text { 1. Informasi terkait perencanaan seperti pembuatan daftar belanja dan rencana makan } \\
\text { yang baik (K). } \\
\text { 2. Aplikasi seluler terkait persediaan makanan (B). }\end{array}$ \\
\hline $\begin{array}{l}\text { Kurangnya kontrol pada inventarisasi } \\
\text { makanan } \\
\text { Belanja }\end{array}$ & 1. Smart fridges $(\mathrm{B})$. \\
\hline Perbedaan selera antar anggota keluarga & $\begin{array}{l}\text { 1. Mempersiapkan menu makanan yang lebih umum disukai semua orang (RT). } \\
\text { 2. Mempersiapkan menu makanan sesuai selera secara bergantian (RT). }\end{array}$ \\
\hline $\begin{array}{l}\text { Pembelian makanan dengan kemasan yang } \\
\text { besar }\end{array}$ & 1. Penyediaan ukuran kemasan yang berbeda-beda dengan harga terjangkau (B). \\
\hline Aspek kepentingan biaya & Meningkatkan kesadaran terkait lingkungan (RT). \\
\hline Frekuensi belanja & 1. Membuat jadwal belanja sesuai dengan ketersediaan makanan (RT). \\
\hline Aksesibilitas belanja & $\begin{array}{l}\text { 1. Menyediakan supermarket atau pasar yang }(\mathrm{B}) \text {. } \\
\text { 2. Menyediakan transportasi umum }(\mathrm{K}) \text {. }\end{array}$ \\
\hline \multicolumn{2}{|l|}{ Penyimpanan } \\
\hline $\begin{array}{l}\text { Penyimpanan yang tidak tepat dan tidak } \\
\text { sistematis }\end{array}$ & $\begin{array}{l}\text { 1. Smart fridges dan desain kulkas yang baik (B, P\&P). } \\
\text { 2. Kontrol suhu yang baik (B). } \\
\text { 3. Pemberian informasi terkait penyimpanan makanan sesuai jenisnya (K). } \\
\text { 4. Meningkatkan kualitas pengemasan makanan (B, P\&P). } \\
\text { 5. Memiliki tempat penyimpanan makanan sesuai dengan kebutuhan (RT). }\end{array}$ \\
\hline
\end{tabular}

\section{Memasak \\ Kemampuan memasak yang kurang baik}

Kurangnya pengetahuan dan kemampuan untuk memasak menggunakan makanan yang tersisa

\section{Praktek Makan}

Makan dengan porsi yang besar

Penanganan makanan tersisa dan pembuangan

Ketidakinginan untuk memakan makanan 1 yang tersisa

Ketidakpercayaan terkait ketahanan makanan yang tersisa

Ketidakpahaman atau ketidakinginan untuk 1 mendaurulang sampah makanan

Keterangan: B: Bisnis, K: Kebijakan, P\&P: Penelitian \& Pengembangan, RT:Rumah Tangga
1. Meningkatkan kemampuan memasak agar dapat menyediakan porsi makanan yang sesuai.

1. Penyediaan informasi resep makanan melalui buku dan platform lain $(B, K)$.

1. Penyediaan makanan dengan porsi yang lebih sedikit (RT).

Membagikan makanan kepada orang lain (RT, B).

Informasi terkait ketahanan dan cara mempertahankan ketahanan makanan (K). Informasi terkait keamanan dan kebersihan makanan (P).

Informasi dan sosiali terkait hierarki sampah dan cara melakukan daur ulang sampah Informasi danan $(\mathrm{P})$ 
Dengan kata lain, sampah makanan menjadi salah satu kontributor tertinggi dalam timbulan sampah sehingga usaha pengurangan sampah juga akan ditargetkan pada sampah makanan. Diperlukan beragam pendekatan dan kombinasi tindakan yang tepat untuk mencapai tujuan yang diinginkan. Pendekatan terkini fokus pada peningkatan kesadaran dan penyediaan informasi untuk memperbaiki kekurangan informasi, memodifikasi sikap, atau mengeliminasi hambatan lain yang ditemukan (Schanes et al., 2018).

Tabel 3 dan Tabel 4 menjelaskan gambaran mekanisme secara umum pencegahan timbulan sampah makanan sesuai dengan faktor-faktor yang mendorong terbentuknya sampah makanan berdasarkan persepsi terhadap makanan dan rutinitas perencanaan makanan sesuai dengan peran yang berkepentingan, yaitu rumah tangga, bisnis, dan kebijakan. Kebijakan memiliki peran tersendiri dalam usaha pencegahan dan pengurangan sampah makanan serta pengelolaan sampah makanan. Kebijakan dilaporkan memiliki hubungan yang signifikan terhadap timbulan sampah makanan (Amirudin \& Gim, 2019; Lee \& Paik, 2011).

\subsection{Praktek Pengelolaan Sampah Makanan di Beberapa Negara \\ 3.3.1 Pengelolaan Sampah Makanan di Singapura}

Singapura hampir tidak memiliki aktivitas agrikultur dan kebanyakan makanan yang tersedia berasal dari luar negeri. Berdasarkan Singapore AgriFood and Veterinary Authority (AVA, 2014), total makanan yang dikonsumsi adalah 2.153.536-ton dan sekitar 33\% dari makanan dibuang pada tahun 2012 (Ng et al., 2015). Pada tahun 2017, timbulan sampah makanan di Singapura setara dengan berat 54.000 double-decker-buses (NEA, 2020). Pengelolaan sampah makanan yang buruk dapat menyebabkan masalah vektor penyakit dan bau serta potensi daur ulang sampah yang menurun.

Pengelolaan sampah secara umum dimulai dari sumber, kemudian sampah akan dikumpulkan menggunakan fasilitas pengumpul menuju fasilitas daur ulang, Waste to Energy (WTE), atau landfill. Hal ini didasarkan pada jenis sampah. Residu yang dihasilkan dari WTE akan disalurkan ke landfill dan logam yang memiliki nilai recovery akan disalurkan ke fasilitas daur ulang. Hasil dari fasilitas daur ulang dan WTE akan diberikan pada industri untuk kemudian digunakan kembali. Gambar 1 berikut menjelaskan alur dari pengelolaan sampah di Singapura.

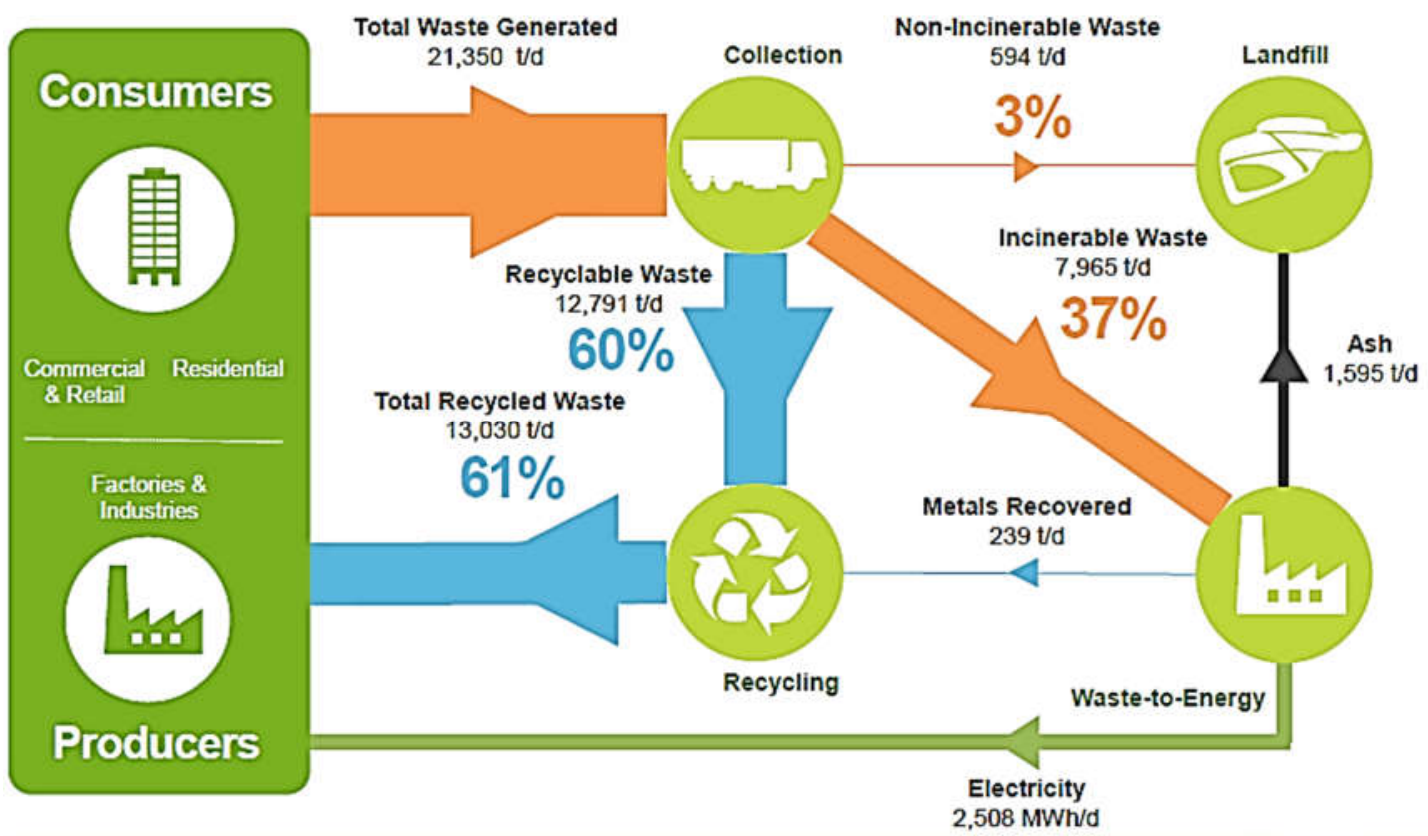

Gambar 1. Pengelolaan Sampah Makanan di Singapura (NEA, 2020)

Setelah melalui tahap pengumpulan, sampah makanan akan dibawa ke pusat fasilitas daur ulang, kecuali apabila ada individu yang mempunyai kesadaran untuk melakukan pembuatan kompos sendiri. Pengolahan sampah makanan terpusat skala besar adalah Anaerobic Digester (AD) yang telah beroperasi dari tahun 2008 di Tuas Singapura. Sementara itu, pengolahan setempat skala kecil berupa Aerobic Composting (AC) dan vermicomposting memiliki peran minor dalam pengolahan sampah makanan di Singapura.

Pembuangan utama sampah makanan di Singapura adalah insinerasi. Selain itu, landfill juga digunakan sebagai metode pembuangan yang umum digunakan ( $\mathrm{Ng}$ et al., 2017). Gambar 2 berikut menunjukan aliran material sampah makanan pada tahun 2003 di Singapura. 


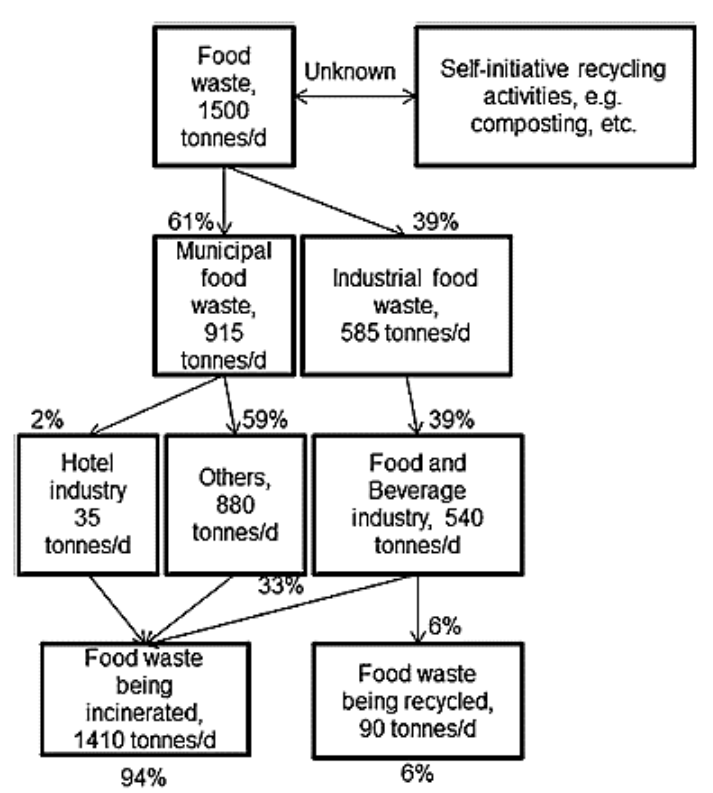

Gambar 2. Aliran Material Sampah Makanan pada tahun 2003 di Singapura (Ng et al., 2017)

National Environment Agency (NEA) telah menetapkan strategi pengelolaan sampah makanan di Singapura. Strategi ini dibentuk melalui suatu hierarki pengelolaan sampah makanan yang didasarkan pada prioritas tertinggi hingga terendah, yaitu:

1. Pencegahan dan Pengurangan Sampah Makanan di Sumber

Program ini dirilis pada November 2015 dan memiliki tujuan untuk meningkatkan kepedulian masyarakat terhadap kondisi sampah makanan terkini dan mendorong masyarakat agar mampu mengadposi kebiasaan yang bijaksana terkait pembelian, penyimpanan, dan persiapan makanan sehingga dapat membantu mengurangi sampah makanan. Selain itu, NEA juga membuat panduan praktis beserta hal-hal mudah yang dapat dilakukan dalam mengurangi sampah makanan dan menyelenggarakan kompetisi resep "Love Your Food" yang bertujuan untuk mendorong masyarakat untuk mengirimkan resep terbaik yang menggunakan jenis makanan sisa yang umum. Lebih dari 500 Food Wastage Reduction Ambbassador direkrut dan dilatih mengenai pengetahuan pengurangan sampah makanan dan mereka bertugas untuk membagikan pengetahuan tersebut kepada teman dan keluarga.

\section{Re-Distribusi Makanan Berlebih / Tidak Terjual}

NEA mendorong masyarakat untuk mendonasikan kelebihan makanan atau makanan yang tidak terjual pada organisasi-organisasi yang akan menyalurkan makanan tersebut ke orang yang membutuhkan. Daftar organisasi-organisasi ini telah dicantumkan dalam panduan praktis pengurangan sampah makanan. Selain itu, terdapat drop box untuk meletakkan makanan yang masih layak makan guna memudahkan masyarakat dalam melakukan donasi makanan.

\section{Daur Ulang / Pengolahan Sampah Makanan}

Untuk melakukan daur ulang atau pengolahan sampah makanan, diperlukan pemilahan sampah di sumber sehingga tidak mengganggu selama proses pengolahan. Saat ini, beberapa rumah tangga telah melakukan pembuatan kompos dari sampah makanan. NEA terus melakukan perbaikan dengan perencanaan adanya sistem pengolahan setempah dan terpusat. Pilot project sistem pengolahan setempat telah dilakukan pada tahun 2016 di beberapa pusat makanan untuk menguji kelayakannya. Di samping itu, NEA juga melakukan pilot project untuk menilai kelayakan pengumpulan dan pengangkutan sampah makanan terpilah menuju fasilitas pengolahan terpusat dimana sampah makanan diolah menggunakan used water sludge untuk dikonversi menjadi biogas. Fasilitas percontohan didesain untuk mengolah hingga 40 ton sampah makanan dan used water sludge per hari.

\section{Energi Recovery}

Sampah makanan yang tidak diolah, dibuang menuju ke fasilitas Waste to Energy (WTE). Pada tahap ini, sampah makanan diolah menggunakan insinerator.

\subsubsection{Pengelolaan Sampah Makanan di Korea Selatan}

Pengelolaan sampah makanan di Korea terus mengalami perkembangan dari tahun 1995 hingga saat ini. Penghasil sampah makanan adalah orang yang harus bertanggungjawab atas sampah yang dihasilkan. Selain itu, berbagai stakeholder juga terlibat dan memiliki peran penting dalam pengelolaan sampah makanan. Pada studi ini, akan dibahas lebih rinci untuk Seoul.

Terdapat 25 Distrik di Seoul Metropolitan Government (SMG). Peraturan daerah (distrik) mengatur tentang tata cara membuang sampah makanan, sedangkan pemerintah pusat mengatur panduan implementasi user fee system yang termasuk pedoman pada tempat sampah, biaya, dan metode pembuangan. Gambar $\mathbf{3}$ berikut ini menyajikan pengelolaan sampah makanan di Seoul.

Di bawah ini adalah penjelasan mengenai tahapan pengelolaan sampah makanan di Seoul (Yoo, 2019):

1. Penanganan Sampah Makanan di Sumber

Masyarakat diwajibkan untuk memilah sampah termasuk sampah makanan. Bagi masyarakat yang melanggar maka akan diberikan penalti. Pewadahan sampah makanan dalam jumlah yang kecil dapat berupa kantong plastik standar, kotak standar dengan chip, atau timbangan otomatis Radio Frequency Identification (RFID). RFID dapata digunakan untuk mengidentifikasi penghasil sampah makanan dan lokasinya. RFID merupakan suatu alat yang efektif guna mengurangi sampah makanan di sumber. Umumnya, RFID diletakkan di apartemen atau restoran besar. 


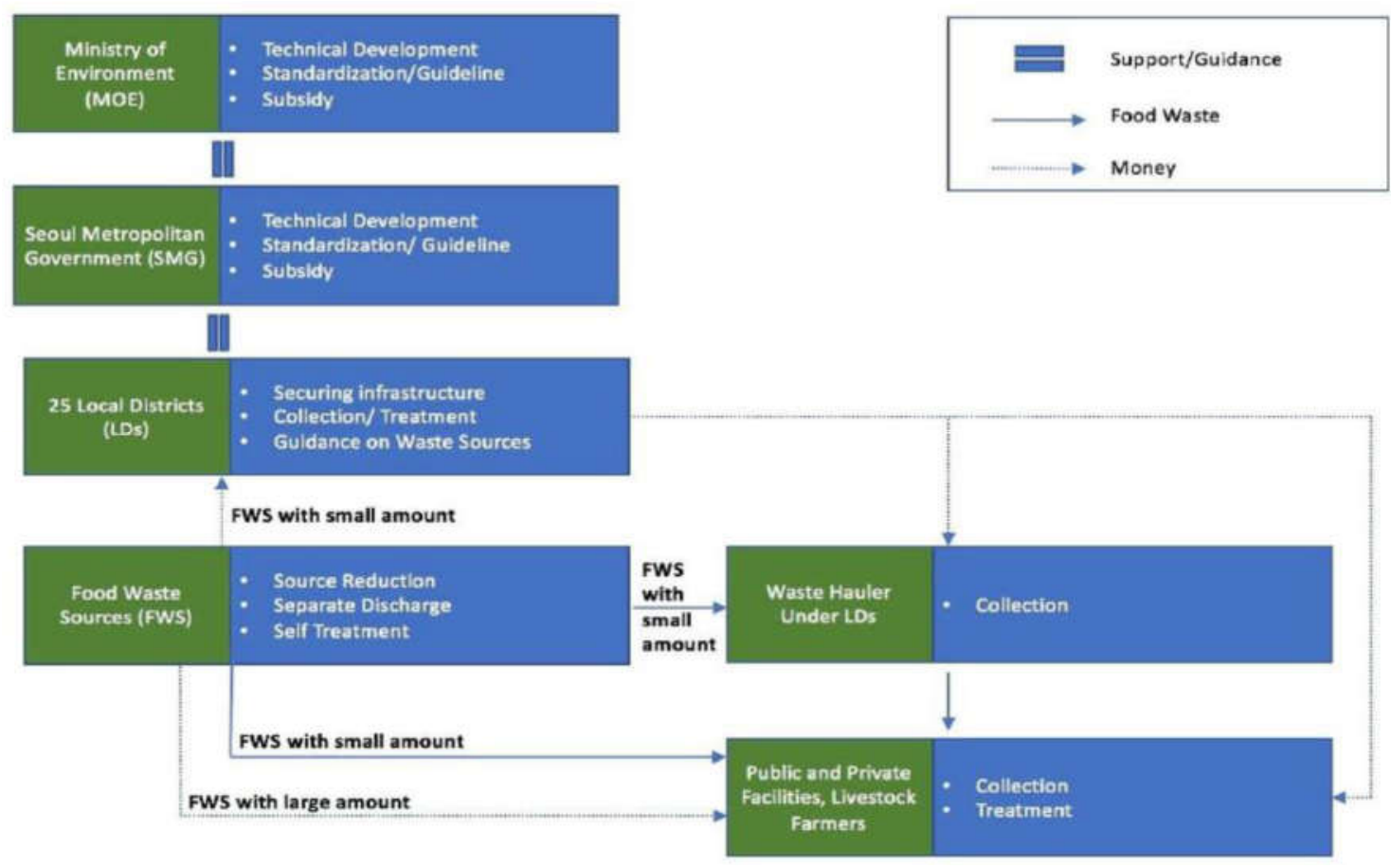

Gambar 3. Pengelolaan Sampah Makanan di Seoul (Yoo, 2019)

\section{Sistem Pengumpulan Sampah Makanan}

Sampah makanan dikumpulkan oleh pengangkut sampah, fasilitas pribadi berlisensi, atau petani yang menggunakan sampah makanan untuk ternak atau kompos. Umumnya, sampah makanan dalam jumlah yang kecil dikumpulkan oleh pengangkut sampah yang dikelola oleh distrik lokal. Pada tahun 2014, terdapat 114 pengangkut sampah resmi di Seoul yang bertugas untuk mengumpulkan sampah makanan 2-3 kali/minggu saat matahari terbenam hingga fajar. Hal ini dilakukan untuk menghindari penglihatan publik.

Terdapat 3 jenis pengumpul sampah yang digunakan, yaitu kendaraan bermuatan 1 ton, 5 ton, dan 11 ton. Kendaraan dengan muatan 5 ton adalah yang paling umum digunakan, sedangkan kendaraan berkapasitas 1 ton digunakan sesekali untuk area tertentu. Untuk kendaraan dengan kapasitas 11 ton digunakan jika lokasi fasilitas pengolahan terletak jauh dari sumber sehingga menghasilkan transportasi yang lebih ekonomis. Sebanyak 500 kendaraan digunakan untuk mengangkut sampah dari sumber ke stasiun transfer atau fasilitas.

\section{Sistem Pengolahan Sampah Makanan}

Sampah makanan terkumpul diolah pada fasilitas yang berlisensi sesuai Ministry of Environment (MOE). Sampah makanan yang dibuang ke landfill terbatas pada sampah makanan yang tidak dapat didaur ulang dan residu dari fasilitas pengolahan. Semua fasilitas pengolahan harus melakukan daur ulang dan recovery setidaknya 70\% dari dried solid food waste yang masuk. Pemerintah menguraikan bahwa sampah makanan dapat dimanfaatkan sebagai: a. Kompos pada tanah pertanian atau makanan untuk hewan ternak.

b. Tanah bagian atas pada landfill atau soil conditioner.

c. Bahan baku untuk fasilitas pembuatan pupuk.

d. Bahan baku untuk fasilitas pembuatan pakan.

e. Absorben polutan melalui proses karbinisasi.

f. Bahan baku untuk menghasilkan biogas menggunakan fermentasi anaerobik.

Terdapat 5 pengolahan sampah makanan di Seoul dengan kapasitas pengolahan mencapai 1.360 ton/hari. Seoul menghasilkan sampah sebesar 3.400 ton/hari dan hanya $1 / 3$ bagian dari total sampah yang dihasilkan dapat diolah di fasilitas pengolahan kota. Sampah makanan yang tersisa akan diolah melalui 30 fasilitas pribadi yang berbeda-beda.

Di Korea, terdapat 240 fasilitas pengolahan sampah makanan termasuk 100 fasiltias publik yang dioperasikan distrik lokal dan 140 fasilitas yang dioperasikan oleh perusahaan pribadi dengan izin pemerintah. Fasilitas publik cenderung untuk mengadopsi metode kompos, sedangkan fasilitas pribadi cenderung menggunakan metode produksi pakan hewan karena membutuhkan waktu yang lebih sedikit, lahan yang lebih kecil, dan bau yang dapat dikendalikan.

Semua fasilitas pengolahan makanan harus diperiksa oleh pemerintah setiap tahun untuk mencegah pembangunan fasilitas yang terlalu besar. Selain itu, pemeriksaan dilakukan untuk memastikan fasilitas beroperasi secara ekonomis dan polutan yang dihasilkan masih memenuhi baku mutu. 


\subsubsection{Pengelolaan Sampah Makanan di Denmark}

Pada review ini, kota yang dibahas adalah Copenhagen. Kota tersebut mulai melaksanakan pengumpulan sampah makanan terpisah pada tahun 2017 dan melaksanakan pada seluruh daerah di Copenhagen pada tahun 2018. Villa atau rumah yang dihuni oleh satu orang tidak diwajibkan untuk berpartisipasi pada program ini. Sekitar 300.000 rumah tangga yang terdiri dari 280.000 rumah tangga dengan anggota lebih dari satu orang dan 20.000 villa ikut mendukung pemilahan sampah. Terdapat pajak pengumpulan dan pengolahan sampah makanan yang perlu dibayarkan untuk mendukung pengelolaan sampah makanan. Pemerintah setempat percaya bahwa pajak yang diberikan akan berkurang pada tahun mendatang dengan masyarakat tetap mendapatkan keuntungan dalam pengelolaan sampah makanan. Biaya pengumpulan dan pengolahan sampah makanan lebih murah dari biaya insinerasi. Pengelolaan sampah di Copenhagen meliputi pewadahan, pengumpulan, dan pengolahan (Jain et al., 2018). Berikut adalah uraian penanganan sampah makanan di Kota Copenhagen, Denmark.

1. Penanganan Sampah Makanan di Sumber

Copenhagen telah mulai menjalankan program pemilahan sampah sehingga sampah makanan terpilah memiliki pewadahan sendiri. Sampah makanan tersebut meliputi makanan mentah dan masak, nasi, pasta, produk sarapan, daging, ikan, tulang, roti, kue, sayur, buah, saus, telur, cangkang telur, kacang, kulit kacang, bubuk kopi, daun teh, saringan teh, tisu kertas bekas, dan bunga. Wadah sampah makanan dapat berupa kantong bioplastik dan wadah sampah berbahan plastik.

\section{Sistem Pengumpulan Sampah Makanan}

Pengumpulan sampah makanan dilakukan oleh perusahaan pengumpul pribadi yang disewa oleh pemerintah melalui tender. Sampah dikumpulkan dari satu rumah ke rumah lain. Sampah makanan dari rumah tangga dengan anggota keluarga lebih dari satu dikumpulkan satu kali dalam seminggu. Sementara itu, sampah makanan dari villa dikumpulkan satu kali dalam 2 minggu, yaitu pada minggu kedua.

\section{Sistem Pengolahan Sampah Makanan}

Sampah makanan diolah melalui Anaerobic Digester (AD) dan didahului dengan pre-treatment. Hal ini dilakukan untuk membentuk bio pulp sehingga cairan tersebut dapat dipompa ke tangki reaktor biogas. Sampah dengan ukuran besar dan sampah yang tidak pada tempatnya dipisahkan dari input $\mathrm{AD}$ selama pre-treatment. $\mathrm{AD}$ dapat mengolah sampah makanan rumah tangga, sampah industri yang berasal dari industri pembuat makanan, industri perikanan, rumah potong hewan, tempat pembuatan bir, dan pupuk kendang. Hasil dari pengolahan AD adalah biogas yang digunakan untuk produksi listrik yang disalurkan ke desa setempat yang terdiri dari 450 rumah. Di masa mendatang, AD dengan desain baru akan dibangun dekat Copenhagen dan biogas akan digunakan untuk kebutuhan kendaraan. Sementara itu, cairan dari pengolahan AD digunakan sebagai pupuk.

Inisiatif dalam pengumpulan dan daur ulang sampah makanan merupakan bagian dari "Resourve and Waste Management Plan 2018" untuk City of Copenhagen. Target daur ulang yang ingin dicapai adalah 45\% pada tahun 2019 dan mengenalkan pemilahan sampah makanan di sumber. Pengangkutan sampah makanan ke landfill telah dilarang sejak tahun 1997.

\subsubsection{Pengelolaan Sampah Makanan di Norwegia}

Pembahasan akan lebih banyak untuk kasus Kota Oslo. Pada tahun 2016, pemerintah Kota Oslo memutuskan untuk melakukan pemisahan sampah rumah tangga di sumber. Hal ini dilakukan dengan adanya fasilitas pemilahan sampah yang pertama kali didirikan pada Oktober 2009. Selanjutnya, terjadi perubahan dan pengembangan fasilitas pengolahan hingga pada musim panas 2013 fasilitas pengolahan biologis di Romerike telah mulai beroperasi. Oslo memiliki tujuan untuk meningkatkan daur ulang sampah makanan hingga $60 \%$ pada tahun 2025 dan mengurangi timbulan sampah makanan hingga $30 \%$.

Biaya pengelolaan sampah berdasarkan nonprofit basis melalui sistem pay-as-you-throw. Rumah tanggga dikenai biaya untuk pengumpulan semua jenis sampah mulai dari €443/tahun untuk tempat sampah dengan kapasitas $140 \mathrm{~L}$.

Sistem pengumpulan sampah terpisah memastikan bahwa tidak ada sampah yang dapat teurai dibuang ke landfill yang telah dilarang pada tahun 2009. Berikut ini adalah pengelolaan sampah yang dilakukan di Oslo (Jain et al., 2018):

1. Penanganan Sampah Makanan di Sumber

Sampah rumah tangga dipisahkan berdasarkan jenisnya dan dimasukkan ke dalam kantong plastik yang telah ditentukan. Penentuan kantong plastik didasarkan oleh warna. Untuk sampah makanan dikumpulkan pada kantong plastik yang berwarna hijau. Sampah makanan dalam plastik berwarna hijau meliputi kulit buah/sayur, roti, kantong the, bubuk kopi, seafood, daging, tulang, cangkang telur, dan sedikit soiled kitchen paper.

\section{Sistem Pengumpulan dan Pemilahan}

Pengumpulan sampah makanan dilakukan setiap minggu dari rumah tangga bersamaan dengan sampah yang lain. Semua sampah yang terkumpul diangkut oleh pemerintah ke pusat pemilahan atau dibawa ke pusat daur ulang oleh individu. Sistem pemilahan didasarkan pada kode warna kantong plastik. Semua sampah dimasukkan ke dalam kontainer yang sama. Sampah dalam kantong plastik dengan kode tertentu dikirim ke pusat pemilahan. 


\section{Sistem Pengolahan Sampah Makanan}

Sampah makanan dari pusat pemilahan akan dikirimkan ke Romerike Biogas Plant. Pada tahap ini, kantong plastic akan dibuka dan sampah selain sampah makanan disisihkan. Proses pengolahan diawali dengan hidrolisis termal dan diikuti dengan pemansan untuk membunuh patoogen dan jamur serta membuat pengolahan menjadi lebih mudah dan cepat. Proses selanjutnya adalah anaerobic digestion pada kondisi mesofilik untuk menghasilkan biogas dan digestate. Biogas ditingkatkan menjadi compressed biogas (CBG) dan liquid biogas (LBG). Digestate diolah menjadi dua produk yang berbeda yaitu, digestate dengan kadar total solid yang tinggi $25 \%$ dan biokonsentrat cair dengan total solid sekitar $15 \%$. Biogas digunakan untuk bahan bakar bus, sedangkan digestate digunakan sebagai pupuk.

\subsection{Analisis Pengelolaan Sampah Makanan di Indonesia}

Indonesia telah memiliki peraturan pengelolaan sampah makanan yang tertuang dalam Undangundang Nomor 18 Tahun 2008. Di dalam peraturan tersebut disebutkan pengelolaan sampah terdiri dari pengurangan sampah dan penanganan sampah. Pengurangan sampah dilakukan dengan cara membatasi timbulan sampah, daur ulang sampah, dan pemanfaatan kembali sampah. Usaha yang berpotensi untuk dilakukan oleh masyarakat Indonesia adalah membatasi timbulan sampah dengan cara yang dilakukan seperti Singapura, yaitu membagikan makanan tersisa yang masih layak makan bagi orang yang membutuhkan. Hal ini dikarenakan Indonesia memiliki budaya gotong royong yang telah tumbuh dan berkembang dalam kehidupan sosial masyarakat Indones (Effendi, 2013) sehingga untuk menolong sesama bukanlah hal yang baru dalam budaya masyarakat Indonesia. Berbeda dengan daur ulang sampah dan pemanfaatan kembali sampah yang membutuhkan pemahaman dan kemampuan tersendiri dalam pelaksanaannya.

Kondisi pengelolaan sampah makanan di Indonesia masih sedikit tertinggal dibandingkan beberapa negara yang telah disebutkan dalam bagian diatas. Diperlukan adanya modifikasi dalam penerapan pengelolaan sampah di Indonesia. Implementasi pengelolaan sampah di Indonesia yang diajukan berdasarkan tinjauan dari beberapa Negara diatas. Adapun rincian rencana pengelolaan sampah makanan yang dapat diaplikasikan di Indonesia adalah sebagai berikut:

1. Pemilahan

Sampah sebaiknya dipilah sesuai dengan jenisnya. Untuk memudahkan pemilahan sampah, pemerintah dapat menentukan wadah yang dapat digunakan. Penentuan wadah sampah dapat mengadopsi pewadahan sampah yang dilakukan di Oslo. Wadah sampah yang digunakan adalah kantong plastik yang memiliki warna yang berbeda untuk setiap jenis sampah. Untuk menghindari adanya penumpukan sampah karena kantong plastik tersebut, kantong plastik dapat didesain untuk beragam ukuran. Selain itu, kualitas kantong plastik sebagai wadah sampah harus diperhatikan agar tahan air dan tidak mudah sobek serta sebaiknya memiliki bahan yang dapat didaur ulang.

\section{Pengumpulan}

Pengumpulan sampah makanan dapat dilakukan secara bersamaan dengan sampah jenis lainnya karena setiap jenis sampah telah terpisah sesuai dengan pewadahannya. Pengumpulan sampah untuk semua jenis sampah akan lebih menghemat waktu. Akan tetapi, jadwal pengumpulan sampah harus diperhatikan, mengingat bahwa sampah makanan memiliki sifat mudah diuraikan sehingga lebih cepat membusuk dibandingkan jenis sampah yang lain. Di samping itu, untuk lebih memudahkan dalam tahap penanganan sampah selanjutnya, alat pengumpul sampah dapat diberi sekat yang berfungsi untuk mengelompokkan sampah berdasarkan jenisnya.

\section{Pengolahan}

Sebelum diolah, sampah akan dipilah berdasarkan jenisnya. Teknologi pengolahan sampah makanan yang mudah untuk diaplikasikan adalah pengomposan. Akan tetapi, pemerintah Indonesia dapat terus mengembangkan teknologi pengolahan sampah makanan lain dalam skala besar dengan mempertimbangkan kriteria ekonomi, teknis, lingkungan, dan sosial. Dalam hal ini, perlu dibangun fasilitas pengolahan yang memadai termasuk area pemilahan sampah, penyimpanan sampah terolah, dan penampung residu. Dalam hal ini, TPS 3R (Tempat Pengolahan Sampah dengan Prinsip Reduce, Reuse, dan Recycle) telah dikembangkan di Indonesia yang berfungsi untuk menerapkan prinsip 3R. Pengembangan TPS 3R dapat terus ditingkatkan dan dievaluasi secara berkala.

\section{Pembuangan}

Sampah makanan yang dibuang adalah sampah makanan yang tidak dapat diolah dan residu hasil pengolahan sampah makanan yang tidak dapat dimanfaatkan kembali. Hal ini dilakukan untuk mengurangi sampah makanan yang terbuang dan mengurangi beban pengolahan di tempat pembuangan akhir. Metode pembuangan yang dapat digunakan adalah sanitary landfill dengan kriteria yang telah ditetapkan dalam Peraturan Menteri Pekerjaan Umum Nomor 3 Tahun 2014 tentang Penyelenggaraan Prasarana dan Sarana Persampahan dalam Penanganan Sampah Rumah Tangga dan Sampah Sejenis Sampah Rumah Tangga. Metode thermal dapat digunakan dengan memperhatikan buangan yang dihasilkan dalam proses pengolahan tidak akan membayahakan lingkungan sekitar. 


\section{Kesimpulan}

Paper ini membahas perilaku dan praktik terkait sampah makanan rumah tangga yang ditinjau dari pemahaman dan persepsi terhadap sampah makanan serta rutinitas perencanaan makanan dalam rumah tangga sehingga dapat ditentukan strategi untuk mengelola sampah makanan. Timbulan sampah makanan di rumah tangga merupakan masalah yang kompleks yang didorong oleh berbagai alasan dan perilaku masing-masing individu. Kesadaran seseorang terkait timbulan sampah makanan, norma personal, dan keyakinan seseorang dalam mengelola sampah makanan dapat mempengaruhi jumlah timbulan sampah makanan. Rutinitas perencanaan makanan yang baik yang terdiri dari persiapan, belanja, penyimpanan, memasak, makan, penanganan makanan tersisa dan pembuangan dapat berpotensi untuk mengurangi timbulan sampah makanan. Terdapat beragam hasil penelitian yang menunjukkan bahwa kondisi sosio-demografi dapat mempengaruhi timbulan sampah makanan. Sementara itu, individu dalam rumah tangga harus mampu menerapkan strategi untuk melakukan pencegahan dan pengurangan sampah makanan. Pembuatan daftar belanja, belanja sesuai dengan kebutuhan, penyimpanan yang tepat dan sistematis, kemampuan memasak yang terasah, pola makan sesuai dengan porsi, dan mengelola sisa makanan merupakan strategi yang dapat diterapkan. Selain itu, pemahaman terkait sampah makanan harus ditingkatkan karena sampah makanan dapat ditinjau dari segi lingkungan, ekonomi, dan sosial.

Pemerintah sebagai pemegang tertinggi kekuasan di suatu negara harus mampu menerapkan pengelolaan sampah yang terpadu. Usaha pencegahan dan pengurangan sampah merupakan usaha awal dalam mencapai target pengurangan sampah makanan. Hal ini dapat dilakukan dengan membagikan makanan yang masih layak pada orang yang membutuhkan. Implementasi pengelolaan sampah makanan yang dapat dilakukan di Indonesia adalah dimulai dari pemilahan sampah makanan dengan memperhatikan kualitas wadah sampah, pengumpulan sampah makanan yang dibedakan dengan sampah jenis lain dan memperhatikan jadwal pengumpualn sampah makanan, pengolahan sampah makanan dengan teknologi tertentu, dan memastikan pembuangan sebagai pilihan terakhir dalam alur hidup sampah makanan.

\section{DAFTAR PUSTAKA}

Abdelradi, F. 2018. Food Waste Behaviour at the Household Level: A Conceptual Framework. Waste Management, 71:485-493.

Amirudin, N. and Gim, T.H.T. 2019. Impact of Perceived Food Accessibility on Household Food Waste Behaviors: A Case of the Klang Valley, Malaysia. Resources, Conservation \& Recycling, 151:104335.

AVA. 2014. Corporate Annual Report. Retrieved from AgriFood and Veterinary Authority:
http://www.ava.gov.sg/NR/rdonlyres/0676D1EBC401-4038-9D8D-

84A01B52DD27/26874/AVA_AR2013Lores.pdf. (diakses pada 9 April 2020).

Damanhuri, E. dan Padmi, T. 2010. Pengelolaan Sampah. Diktat Pengelolaan Sampah, Teknik Lingkungan ITB, Bandung.

Effendi, T.N. 2013. Budaya Gotong Royong Masyarakat dalam Perubahan Sosial Saat Ini. Jurnal Pemikiran Sosiologi, 2(1):1-18.

FA0. 2011. Global Food Losses and Food Waste - Extent, Causes, and Prevention. Retrieved from http://www.fao.org/3/a-i2697e.pdf (diakses pada 9 April 2020).

FUSIONS. 2014. FUSIONS Reports: "FUSIONS Definitional Framework for Food Waste". Cordis, European Commission.

Graham-Rowe, E. and D. Jessop, P. Sparks. 2014. Identifying Motivations and Barriers to Minimising Household Food Waste. Resources, Conservation \& Recycling, 84:15-23.

Grasso, A.C and M.R. Olthof, A.J. Boeve, C. van Dooren, L. Lahteenmaki, I.A. Brouwer. 2019. Socio-Demographic Predictors of Food Waste Behavior in Denmark and Spain. Sustainability, 11(2):3244.

Hebrok, M. and C. Boks. 2017. Household Food Waste: Drivers and Potential Intervention Points for Design An Extensive Review. Journal of Cleaner Production, 151:380-392.

Ilyuk, V. 2018. Like Throwing a Piece of Me Away: How Online and In-Store Grocery Purchase Channels Affect Consumers' Food Waste. Journal of Retailing and Consumer Services, 41:20-30.

Jain, S. and D. Newman, R. Cepeda-Marquez, K. Zeller. 2018. Global Food Waste Management: An Implementation Guide for Cities. World Biogas Association.

Koivopuro, H.K. and H. Hartikainen, K. Silvennoinen, J.M. Katajajuuri, N. Heikintalo, A. Reinikainen, L. Jalkanen. 2012. Influence of Socio-Demographical, Behavioural and Attitudinal Factors on the Amount of Avoidable Food Waste Generated in Finnish Households. International Journal of Consumer Studies. 36:183191.

Lee, S. and H.S. Paik. 2011. Korean Household Management and Recycling Behavior. Building and Environment, 46(5):1159-1166.

Lim, W. and N. Chin, A. Yusof, A. Yahya, T. Tee. 2016. Food Waste Handling in Malaysia and Comparison with Other Asian Countries. Internation Food Research Journal, 23 (suppl.):S1-S6.

Mattar, L. and M.G. Abiad, A. Chalak, M. Diab, H. Hassan. 2018. Attitudes and Behaviors Shaping Household Food Waste Generation: Lessons from Lebanon. Journal of Cleaner Production, 198:1219-1223.

NEA. 2020. Food Waste Management. Retrieved from National Environmental Agency Website: https://www.nea.gov.sg (diakses pada 9 April 2020).

Neff, R.A and M.L. Spiker, P.L. Truant. 2015. Wasted Food: US Consumers' Reported Awareness, Attitudes, and Behaviors. PLoS ONE, 10(6):e0127881.

Ng, B.J.H and Y. Mao, C. Chen, R. Rajagopal, J. Wang. 2017. Municipal Food Waste Management in Singapore: Practices, Challenges, and Recommendations. Journal of Material Cycles and Waste Management, 19(1):560569. 
Nikolaus, C. J. and M.S. Nickols-Richardson, B. Ellison. 2018. Wasted Food: A Qualitative Study of U.S. Young Adults' Perceptions, Beliefs and Behaviors. Appetite, 130:7078.

Nikolaus, C.J. and Nickols-Richardson, S.M., Ellison, B. 2018. Wasted Food: A Qualitative Study of U.S. Young Adults' Perceptions, Beliefs and Behaviors. Appetite, 130:7078.

Parfitt, J. and M. Barthel, S. Macnaughton. 2010. Food Waste Within Food Supply Chains: Quantification and Potential for Change to 2050. Philosophical Transactions of The Royal Society B, 365:3065-3081.

Russel, S. and C.W. Young, K.L. Unsworth, C. Robinson. 2017. Bringing Habits and Emotions into Food Waste Behavior. Resources, Conservation \& Recycling, 125:107-114.
Schanes, K. and K. Dobernig, B. Gozet. 2018. Food Waste matters - A Systematic Review of Household Food Waste Pracatices and Their Policy Implications. Journal of Cleaner Production, 182:978-991.

Van der Werf, P and J.A. Seabrook, J.A. Gilliland. 2019. Food for Naught: Using the Theory of Planned Behavior to Better Understand Household Food Wasting Behavior. The Canadian Geographer, 63(3):478-493.

Visschers, V.H.M and N. Wickli, M. Siegrist. 2016. Sorting Out Food Waste Behaviour: A Survey on the Motivators and Barriers of Self-Reported Amounts of Food Waste in Households. Journal of Environmental Psychology, 45:66-78.

Yoo, K.Y. 2019. Food Waste Management in Korea: Focusing on Seoul, Republic of Korea. UNDP. 